\title{
COMMENT
}

\section{Motivational success story from Egypt}

\author{
Rania A. El-Farrash (D) \\ Pediatric Research (2020) 87:619; https://doi.org/10.1038/s41390-019-0670-7
}

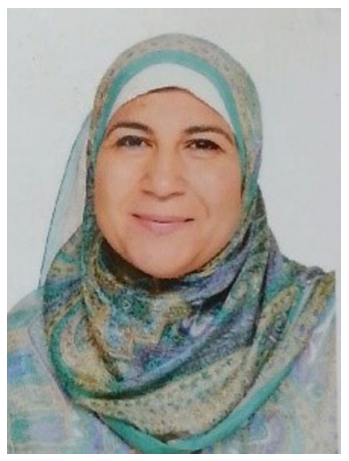

I am Rania A. El-Farrash, Professor of Pediatrics and Consultant Neonatologist at the tertiary neonatal intensive care units of the Children's Hospital, Ain Shams University in Cairo, Egypt. I grew up here in Cairo, which is the capital of Egypt, and the largest city in the Middle East, perhaps most well-known for its association with the Giza pyramid complex. My biggest influence growing up had been my father. He is a retired Professor of Nuclear Physics. When I was younger, he used to invite his international colleagues to spend a few days in our home, and I remember enjoying going with them to their sightseeing tours in Egypt. Now, as a co-founder of the Ain Shams Society for Neonatal Care and Continuous Medical Education, I have started several international collaborations and, like father, like daughter, I, too, invited many international speakers to our conferences and took my daughter with me for their sightseeing tours.

I earned my Bachelor's degree in medicine in 1997 from the Faculty of Medicine, Ain Shams University. I loved every rotation I did in medical school but when I got into pediatrics, I fell in love with kids and developed skills in interacting with them which I consider the best thing that ever happened to me. It was truly a great opportunity to work as an intern at the Children's Hospital of Ain Shams University during which I've completed my Master's degree in Pediatrics. During my residency, I felt like wanting to do something more exciting than general pediatrics; neonatology was the perfect fit for me. My Doctorate thesis on renal structural and functional integrity in ABO-hemolytic disease of newborns was under the supervision of Prof. Hicham Awad, my mentor. The work for this thesis was accomplished from 2002 until 2007, while I was a registrar in the Pediatric Department.

In the research field, I owe much to Prof. Yehia El-Gamal. He was a true inspiration to me and taught me to focus on research and publication. Also, I owe much to my supervisor Dr. Eman Ismail for her constant encouragement and heartfelt devotion. I have been blessed with getting training and leadership from many leading pediatricians, and neonatologists.

I was appointed a senior lecturer in 2008 and promoted to Assistant Professor in 2013, then recently, I've become a Professor in 2018. In 2013, there was a turning point in my clinical career, as I became an International Board-Certified Lactation Consultant. Since 2014, I have served as one of the local assessors for the Baby Friendly Hospitals in Egypt and as a coordinator for Baby Friendly Hospital Initiatives at Ain Shams University. There was another turning point in 2014, when I earned an International Fellowship of the American Association of Respiratory Care, then was elected as Egypt's representative at the International Council for Respiratory Care since 2015. Recently in 2019, I became a Neonatal Life Support full instructor.

Publication wise, I publish and review papers in international scientific journals and have presented many posters in international conferences. I have written a chapter on Neonatal Pulmonary Disorders in the Neonatal and Pediatric Respiratory Care (4th edn. Walsh, B.K., ed. 2015, Elsevier). I received my first national award in 2013: A state incentive award in medicine by the Egyptian Academy of Scientific Research and Technology for academic achievements in clinical research and international academia as well as in medical education and clinical care.

It has been an immense pleasure to devote my time and effort in this field, and to face the challenges that come with achieving goals and making a difference. I encourage my junior colleagues to go on pursuing their education and exploit every chance to enlarge their knowledge base and improve their skills.

\section{ADDITIONAL INFORMATION}

Competing interests: The author declares no competing interests.

Publisher's note Springer Nature remains neutral with regard to jurisdictional claims in published maps and institutional affiliations.

${ }^{1}$ Neonatal Intensive Care Unit, Children's Hospital, Ain Shams University, Cairo, Egypt

Correspondence: Rania A. El-Farrash (rania.elfarrash@med.asu.edu.eg)

Received: 16 September 2019 Accepted: 7 October 2019

Published online: 9 November 2019 